\title{
URBAN CONSUMER WILLINGNESS TO PAY FOR INTRODUCED DESSERT BANANAS IN UGANDA
}

\author{
J. MUGISHA ${ }^{1}, \mathrm{~K}$. AKANKWASA, W. TUSHEMEREIRWE and P. RAGAMA \\ ${ }^{1}$ Department of Agricultural Economics and Agribusiness, Makerere University, Kampala, Uganda \\ National Agricultural Research Organization (NARO) P.O. Box 7065, Kampala, Uganda
}

(Received 18 January, 2009; accepted 2 June, 2009)

\begin{abstract}
Dessert bananas (Musa spp.) form one of the world's most important fruits, yet one of the least traded commodities in Uganda. A range of exotic and hybrid dessert bananas that included KABANA 3H and KABANA 4H were introduced in Uganda in response to Fusarium wilt disease that was wiping away Gros Michel. However, the effect of dessert attributes and consumer characteristics on consumers' willingness to pay for these new bananas among the urban consumers was not known. This study was undertaken to determine awareness of the introduced dessert bananas among urban consumers, and the effect of introduced dessert banana attributes and consumer characteristics on willingness to pay for the introduced desert bananas. Results indicated that urban consumers had low awareness on the introduced dessert banana varieties. Similarly the introduced dessert bananas were acceptable to consumers though rated inferior to Gros Michel. All the sensory attributes of KABANA $3 \mathrm{H}$ and KABANA $4 \mathrm{H}$ were acceptable to urban consumers. Results from the hedonic pricing Models further suggested that taste, skin colour and texture had significant effect on the consumer willingness to pay for new dessert banana varieties. It is concluded that, the three introduced dessert bananas are acceptable and therefore have a market potential. It is recommended that market development activities including organising and training farmers in improved agronomic methods, handling bananas for local markets; and promotional studies of the introduced dessert bananas among the urban consumers be done to widen their demand.
\end{abstract}

Key Words: Fusarium wilt, Gros Michel, hedonic model, Musa spp.

\section{RÉSUMÉ}

Les bananes dessert (Musa spp.) représentent les fruits les plus importants de l'univers, et pourtant l'un des marchandises les moins négociés en Ouganda. Une gamme de bananes dessert exotiques et hybride qui incluait KABANA $3 \mathrm{H}$ et KABANA $4 \mathrm{H}$ avaient été introduits en Ouganda en réponse à la maladie de flétrissement par Fusarium qui avait éliminé Gros Michel. Toutefois, l'effet des attributs de la banane dessert et les caractéristiques de la préférence à acheter ces bananes parmi les consommateurs urbains n'était pas connu. Cette étude avait été entreprise afin de déterminer la connaissance du consommateur sur les bananes dessert introduites chez les consommateurs urbains et l'effet des attributs des bananes dessert introduites ainsi que les caractéristiques du consommateur par rapport à la préférence d'acheter les bananes désert introduites. Les résultats indiquaient que les consommateurs urbains avaient une moindre information sur les variétés de banane dessert introduites. De même, les bananes dessert introduites étaient acceptables par les consommateurs bien qu'à un taux nominal faible pour Gros Michel. Tout les attributs sensorielles de KABANA $3 \mathrm{H}$ et KABANA $4 \mathrm{H}$ étaient acceptables pour les consommateurs urbains. En plus Les résultats des Modèles de tarification hedonic suggèrent que la saveur, couleur de peau et la texture avaient un effet significatif sur la motivation du consommateur à acheter de nouvelles variétés de banane dessert. Il est conclu que les trois variété de bananes dessert introduites avaient un marché potentiel important. Il est recommandé que les activités de développement du marché, y compris l'organisation et la formation des agriculteurs sur l'amélioration des pratiques agronomiques, gestion des bananes pour les 
marchés locaux; ainsi que les études promotionnelles sur la banane dessert introduite chez les consommateurs urbains se fasse afin d'accroître leur demande.

Mots Clés: Flétrissement par Fusarium, Gros Michel, modèle hedonic, Musa spp.

\section{INTRODUCTION}

Dessert bananas form one of the world's most important fruits. Over $85 \%$ of the total world banana production is made up of bananas and plantain varieties grown by small holder farmers, mainly for home consumption (Gowen, 1995). In Africa, banana production is estimated at 33,322 million tonnes of which $29.7 \%$ is produced in Uganda (FAO, 2002). The annual production in Uganda is estimated at 1,646 million tonnes (Uganda Export Promotions Board, 2003). More than $85 \%$ of bananas in Uganda are East African highland types (Musa spp. AAA genotypes, "matooke” and “AAA-EA “mbidde”) (Karamura et al., 1996).

Banana production in Uganda provides subsistence and cash incomes to producers and livelihood to transporters and dealers in its trade (FAO, 2002). However, this industry has been facing many problems that include; low genetic diversity, poor quality of the bananas, poor handling systems and unorganized producers (IDEA, 1998). These problems are further complicated by banana diseases, mainly Fusarium wilt, bacterial wilt and Black sigatoka. These are threatening Gros Michel (Bogoya) and Apple banana (Sukali-Ndizi), causing decline in yield and poor quality fruits (Tushemereirwe et al., 1999). Gros Michel and Apple bananas are highly susceptible to Fusarium wilt (Kangire, 1999). Some companies dealing in export business of Gros Michel and Apple bananas have lost their contract farmers because the disease has caused yield to decline or wiped out their plantations (NBRP, 1999). It is possible that in years to come, Gros Michel may be wiped out completely from farmers' fields.

As part of the interventions, the Uganda National Banana Research Programme has since 1989 introduced, evaluated the agronomic performance and released to farmers improved dessert banana hybrids (KABANA 3H, KABANA 4H, and Cavendish). These hybrids are high yielding and resistant or tolerant to diseases and pests (Tushemereirwe et al., 1999).

Recent studies have investigated the consumer acceptability of these bananas among farming communities for cooking and dessert culinary qualities and some of the introduced genotypes were found to have acceptable attributes (Nowakunda et al., 2000; 2001). One of the objectives of introducing these new hybrids was to increase productivity, and indirectly increase surplus for sale. However, the ultimate urban consumers were not included in the previous evaluation studies. Knowing dessert qualities that are acceptable to the end users/ consumers and influence their willingness to pay for the bananas will enable research and farmers to produce hybrids with acceptable end-user attributes.

The objectives of this study were to determine attributes of dessert bananas considered important by urban consumers, and to assess the effect of introduced dessert banana attributes and consumer characteristics on willingness to pay for the introduced bananas.

\section{METHODOLOGY}

The study was conducted in Kampala City due to its high urban population that implies a high market potential compared to other towns in Uganda. It is composed of five administrative divisions (Kawempe, Makindye, Nakawa, Lubaga and central division). Markets in Lubaga and Nakawa divisions were sampled randomly from a list of other divisions.

Sampling and data collection. The respondents included urban households that purchase and consume dessert bananas. These were selected using a multistage simple random and purposive sampling procedure. Two divisions were randomly selected (Nakawa and Rubaga) from the five divisions. In each selected division, two parishes were also randomly selected namely: 
Luzira and Bukoto (located in Nakawa division); and Nateete and Kabowa (located in Rubaga division). Two zones were further selected randomly from each parish, making a total of eight zones.

From each zone, a list of all households was prepared in consultation with Local Council officials. Using the bowl and fish method, ten households were randomly selected from each zone giving a total sample of eighty. The local markets in which the introduced dessert bananas were tasted (sensory evaluation) were purposively selected from a list of eight major markets, which handle the highest volumes of dessert bananas in Kampala district (Ferris et al., 2002). Four markets including Nakawa, Nakasero, Wandegeya and Kalerwe were selected from the list. In these markets, lists of dessert banana traders were prepared with the assistance of market administration. Ten traders were randomly selected from each market, giving a total number of forty traders as respondents. Each trader received four samples of four introduced dessert bananas (KABANA 3H, KABANA 4H, Cavendish and Gros Michel) for sensory evaluation.

Banana samples were obtained from farmers' fields in Luwero, Mbarara and Bushenyi districts. Banana bunches were harvested at full maturity stage, dehanded, naturally ripened through heaping them in boxes lined with banana leaves. At the full stage of ripeness, the bananas were cleaned by washing, graded and packaged in card boxes. Each of the test dessert banana samples was packaged in a separate box, labeled, and delivered to consumers and traders for sensory testing.

Data were collected using pre-tested structured questionnaires between February and August 2005. The questionnaires were designed to elicit information on the socio-economic characteristics of the respondents' household expenditure, willingness to pay and attributes of four dessert banana varieties; KABANA $3 \mathrm{H}$, KABANA 4H, Cavendish, and Gros Michel a reference variety. Each respondent was given ripe dessert banana samples to evaluate sensory attributes including skin colour, pulp colour, taste, flavour, texture, and acceptability. The banana samples were coded to eliminate name bias.
Evaluation of the attributes was based on a fivepoint hedonic scale (5=Excellent, $4=$ good, 3 = fair, $2=$ bad, 1= Very bad). Also, respondents were asked to rank the four dessert bananas (KABANA 3H, KABANA 4H, Cavendish and Gros Michel) as highly liked, Liked, Slightly liked, Not liked or Not liked at all (Wessells and Anderson, 1995). They were then asked an open ended question of how much they were willing to pay (Carlsson et al., 2004) per cluster of the different samples. They were given the chance of rearranging their ranks until they were completely satisfied that the rankings and willingness to pay values were representative of their preferences.

Analytical methods. Data on socio-economic characteristics of respondents and consumer evaluation of dessert attributes, were coded and summarised. Descriptive statistics were generated using STATA package Version 8.0 and SAS version 9.1 (SAS Institute Inc, 1989).

To determine the effect of banana attributes and consumer characteristics on willingness to pay for introduced desert bananas, a hedonic pricing model (Rosen, 1974), was used to capture the relative importance of banana attributes and consumer characteristics in determining the prices consumers were willing to pay. Consumer willingness to pay for introduced dessert banana hybrids was estimated by using multiple regression analysis using STATA software. The price consumers would pay for each dessert banana variety was regressed on respective scores of each dessert attributes and the study commenced with mean estimates for ordinary least squares (OLS).

A number of models were run in order to avoid omitted model variable bias for each dessert type; product attributes only, socio-economic characteristics only; product attributes and socioeconomic characteristics; and product attributes, socio-economic characteristics and interactions (sex with taste; age with taste were estimated). After running all the four regressions for each dessert type, it was found that only the product attributes and socio-economic characteristics were consistent in the significance of results. However, the interaction terms of attributes with personal characteristics were not. Using 
multicollinearity analyses highly correlated variables were dropped (Allison, 1999).

Empirical model specification. A hedonic price approach postulates that the price of a good is a function of the characteristics of the good (Ahmadi-Esfahani and Stanmore, 1997). It is based on the assumption that the consumer's demand is derived from the levels of characteristics that a good possesses. This allows the price of the product to be decomposed into the parts expressing the contribution of specific attributes to the overall utility gained from consuming the product. The utility gained also depends on the socio-economic characteristics of the consumer such as age, education, gender, income, and household composition.

The concept underlying hedonic models is that the price of a heterogeneous good is a function of the attributes of that good (Larue, 1991). The model's implication, then tries to capture the relative importance of each of the attributes of a good in determining price (Ladd and Lapan, 1976). A hedonic model suggests that the price consumers are willing to pay for a product, such as introduced dessert banana varieties, is a function of its attributes (Hayes et al., 2000). According to Rosen (1974), goods posses a myriad of attributes that combine to form bundles of characteristics, which the consumer values. He estimated hedonic pricing models to examine how product attributes affect price in a perfectly competitive market.

The approach is based on the assumptions of perfect competition and utility maximisation. That is, all the participants are price-takers and have full information and the product is assumed to be purchased by consumers for its attributes. This approach has been applied in many contexts to estimate the implicit prices or the values of non-market goods (attributes). The functional form for consumer's willingness to pay for each of the four dessert banana type was:

$P_{i}=f\left(V_{i}, C_{i}, A w_{i}\right)$ 1

$P_{i=}=$ The price that consumers were willing to pay for dessert variety;
$\mathrm{V}_{i}=\quad$ A vector of implicit prices for variety attributes including skin colour, pulp colour, texture, taste;

$\mathrm{C}_{i}=\mathrm{A}$ vector of consumer characteristics including, age, education, income, sex; and

$A w_{i}=$ Awareness of introduced dessert bananas

The estimated form was derived by a regression of each banana variety price consumers were willing to pay against attributes that each variety possessed. This yielded estimates of marginal implicit prices of each attribute (Motameni and Shahrokhi, 1998). The relationship between the willingness to pay for dessert banana varieties and their determinants was specified as:

$P_{i}=X_{0}+X_{1}$ skcol $_{i}+X_{2}$ pcol $_{i}+X_{3}$ tast $_{i}+X_{4}$ flv $_{i}+$ $X_{5}$ tex $_{i}+X_{6} a w r_{i}+X_{7}$ ageres $_{i}+X_{8}$ educhd $+X_{9}$ inc $_{i}$ $+X_{10}$ sexhhd $_{i}+X_{11}$ hhsize $_{i+} \varepsilon_{i} \ldots \ldots \ldots \ldots \ldots \ldots \ldots \ldots \ldots . . . .2$

Where:

$P_{i}=$ the price of dessert variety ${ }_{i}$ consumers were willing to pay in Uganda shillings (Ug sh) per dessert type.

$X_{0}=$ intercept;

$X_{1}-X_{11}=$ parameters estimated;

skcol $=$ skin colour of dessert banana type. This is the visual attribute that consumers can perceive by looking at a product (Bryan et al., 1996);

pcol $=$ pulp colour. This is the visual attribute that consumers can perceive by looking at the inner part of the dessert when the skin has been peeled off;

tast $=$ taste of the dessert type. This is the sensory stimulation that is produced by the ingestion of food;

$f l v=$ flavour of the dessert type. Flavour is a combination of sensations one feels after taking 
any edible product in the mouth (Deodhar and Intodia, 2002);

tex $=$ texture. This is the hardness or softness of the dessert banana while chewing;

$a w r=$ awareness of introduced dessert banana varieties. This variable was assigned 1 if a respondent was aware and had seen, Gros Michel, Cavendish, KABANA $3 \mathrm{H}$, and KABANA $4 \mathrm{H}$, or 0 if s/he was not aware and had never seen them before;

ageres $=$ age of a respondent measured in complete years;

educhd=number of years respondent spent in school (Measured in years spent in school);

inc $=$ income of the respondent. This was the respondents' own estimation of their annual cash earnings;

sexres $=$ Sex of the respondent. The variable was assigned a value of 1 if the respondent was female and 0 for male;

hhsize $=$ Household size; the number of family members in the household; and

$\varepsilon_{i}=$ Error term

\section{RESULTS AND DISCUSSION}

Socio-economic characteristics of urban dessert banana consumers. The average household family size had 5 persons composed of 3 children ( $<18$ years) and two adults. Of the 124 respondents $(66.1 \%)$ were female and the rest males. About $37.5 \%$ of the total household size were composed of dependants. The average monthly income of the respondents was Ugshs 139,266 (about US\$ 76), which translates into US\$ 2.5 per household/day. This is more than $\$ 1$ per day (the poverty line) (United Nations, 2006) implying high purchasing power. More than 50\% of the respondents were involved in petty trade as their major occupation and source of income. The average level of formal education attained by respondents was above the 7 years required for primary education in Ugandan curriculum. Male respondents were slightly more educated than females.

Consumer awareness of introduced dessert banana varieties. Survey findings show that the majority of the respondents did not know about the introduced dessert banana varieties, confirming that the bananas were not yet well known on the market (Table 1). Only a few respondents had seen Cavendish, KABANA $3 \mathrm{H}$ and KABANA $4 \mathrm{H}$ in some farmers' fields and traders in markets. A relatively big number of the urban consumers had seen KABANA 3H, among the introduced varieties.

However, the majority of the consumers identified Gros Michel easily. It is a familiar dessert known to most of the consumers because it has been on market for many years.

The results of urban consumer evaluation for skin colour, pulp colour, taste, flavour, texture and acceptability for the bananas are presented in Table 2. Gros Michel was found to be superior to all the introduced dessert bananas with respect to all attributes, except skin colour, which was not significantly different $(\mathrm{P}>0.05)$ from that of KABANA 3H (Table 2).

KABANA $3 \mathrm{H}$ had a significantly $(\mathrm{p}<0.05)$ higher score for skin colour than all the introduced dessert bananas, while Cavendish had the least score. Compared with Gros Michel, a reference variety in this study, KABANA $3 \mathrm{H}$ had a higher score although the difference was not significant $(\mathrm{P}>0.05)$. Once ripened, Cavendish developed black spots on the skin which could have influenced consumer's choices. Nowakunda (2001) also found that KABANA 3H had a significantly $(\mathrm{p}<0.05)$ better appealing skin colour than the rest of test varieties when tested on farm.

TABLE 1. Responses of consumers' awareness of introduced dessert bananas in Kampala City

\begin{tabular}{lc}
\hline Dessert type & $\begin{array}{c}\text { Aware of introduced dessert } \\
\text { bananas (\%) }(n=124)\end{array}$ \\
\hline Cavendish & 25 \\
Gros Michel & 53 \\
KABANA 3H & 37 \\
KABANA 4H & 22 \\
\hline
\end{tabular}


TABLE 2. Introduced dessert banana sensory attributes of residents in Kampala City

\begin{tabular}{|c|c|c|c|c|c|c|}
\hline Cultivar type & Skin colour & Pulp colour & Taste & Flavour & Texture & Acceptability \\
\hline Cavendish & $3.39^{c}$ & $3.72^{\mathrm{cb}}$ & $3.93^{b}$ & $3.97^{b}$ & $3.63^{b}$ & $3.74^{b}$ \\
\hline Gros Michel & $4.23^{a}$ & $4.32^{a}$ & $4.48^{a}$ & $4.38^{a}$ & $4.38^{a}$ & $4.36^{a}$ \\
\hline KABANA $3 \mathrm{H}$ & $4.35^{\mathrm{a}}$ & $3.99^{b}$ & $3.35^{c}$ & $3.14^{c}$ & $3.64^{b}$ & $3.22^{c}$ \\
\hline KABANA $4 \mathrm{H}$ & $3.88^{b}$ & $3.65^{c}$ & $3.62^{c}$ & $3.38^{c}$ & $3.54^{b}$ & $3.30^{c}$ \\
\hline C.V (\%) & 29.53 & 21.26 & 23.87 & 0.23 & 24.13 & 28.43 \\
\hline F. Value & $29.52^{\star \star \star}$ & $16.07^{\star \star \star}$ & $34.53^{\star \star \star}$ & $47.22^{\star \star \star}$ & $22.27^{\star \star \star}$ & $30.77^{\star \star \star}$ \\
\hline
\end{tabular}

Means with the same letter in the same column are not significantly different at $(P>0.05)$

*Scale: 1=Very bad, 2 =Bad, 3= Fair 4=Good 5= Excellent

Pulp colour of all the introduced dessert bananas was significantly $(\mathrm{P}<0.05)$ inferior to the reference sample (Gros Michel), an existing commercial dessert banana variety. However, the scores for all the introduced dessert bananas were above 3.0, implying that they all have an acceptable pulp colour. Again, KABANA3H was closest to the reference variety (Gros Michel) with an average score of 3.99. It was not significantly different from that of Cavendish. The pulp colour of KABANA 4H was scored as the least preferred among the introduced dessert bananas (Table 2).

The results of consumer evaluation on taste attribute of introduced dessert bananas indicated that Gros Michel was superior to all dessert bananas under tests. Consumers, however, scored the taste of all the introduced dessert bananas as acceptable as well (i.e. above 3.0). Cavendish was rated as the closest variety to Gros Michel (Table 2). KABANA $3 \mathrm{H}$ and KABANA $4 \mathrm{H}$ were scored as not significantly ( $>0.05$ ) different from each other, while KABANA $3 \mathrm{H}$ had the least score. Nowakunda et al. (2001) found that the taste for Gros Michel was superior to all the introduced bananas, though they had a consumer acceptable taste which is inconsistence with our results.

Results of evaluation of flavour showed that Gros Michel was superior to that of the new banana varieties (Table 2). However, their average scores were above 3.0 indicating that their flavour was generally acceptable to consumers. Cavendish was the closest to the reference variety but significantly $(\mathrm{p}<0.05)$ higher than KABANA $3 \mathrm{H}$ and KABANA $4 \mathrm{H}$. The average consumer scores for texture of all the introduced dessert bananas indicated that Gros Michel was still superior. All the introduced dessert bananas were not significantly ( $\mathrm{p}>0.05)$ different with respect to the texture attribute. Consumers commented that these dessert bananas had a soft texture (Table 2). Overall, the three introduced dessert bananas were acceptable by consumers.

Factors affecting consumer's willingness to pay for introduced dessert bananas. In all estimated hedonic pricing models for the dessert banana varieties, dessert and consumer specific variables, household size, respondent's income, education of the respondent, respondent gender, taste, texture, pulp colour, skin colour and awareness were included. Results are presented in Table 3.

In model 1 , it was only taste that was found to have a statistically significant effect on the consumer willingness to pay for Cavendish although texture and education of the respondents had a positive effect. In the KABANA 3H model, taste and skin appearance were found to be statistically significant. The signs of these coefficients were as expected in respect to the urban consumer' willingness to pay for KABANA 3H. This confirms that the taste for KABANA 3H was acceptable to consumers. Nowakunda et al. (2001) found that taste (sweetness) of KABANA 3H was acceptable to farming communities. Urban consumers who considered KABANA $4 \mathrm{H}$ to be superior with respect to texture are more willing to pay for this variety. Regarding consumer specific variables, coefficients were not significant in respect to 
TABLE 3. Regression coefficients for Hedonic Pricing Models for dessert bananas

\begin{tabular}{|c|c|c|c|c|c|c|c|c|}
\hline \multirow{3}{*}{ Variable } & \multicolumn{8}{|c|}{ Variety type } \\
\hline & \multicolumn{2}{|c|}{ Cavendish } & \multicolumn{2}{|c|}{ Gros Michel } & \multicolumn{2}{|c|}{ KABANA $3 \mathrm{H}$} & \multicolumn{2}{|c|}{ KABANA $4 \mathrm{H}$} \\
\hline & Coef & t value & Coef & t.value & Coef & t value & Coef & t value \\
\hline Household size & 0.17 & 1.21 & 0.32 & $2.38^{\star \star}$ & 0.27 & $1.68^{*}$ & 0.11 & 0.77 \\
\hline Respondent's income & -0.00 & $-2.89^{\text {wat }}$ & -0.00 & -1.52 & 0.00 & -0.85 & -0.00 & -0.83 \\
\hline Education of the respondent & 0.01 & 0.79 & 0.02 & 0.99 & 0.01 & 0.62 & -0.01 & -0.60 \\
\hline $\begin{array}{l}\text { Respondent gender (Female }=1 \text {, } \\
\text { male }=0 \text { ) }\end{array}$ & -0.02 & -0.09 & -0.18 & -0.97 & -0.33 & $-1.70^{*}$ & -0.01 & -0.05 \\
\hline Ascore for the Taste & 0.11 & $2.01^{* *}$ & NA & NA & 0.20 & $2.39^{* *}$ & 0.13 & 1.21 \\
\hline Ascore for the Texture & 0.01 & 1.14 & 0.21 & 1.41 & 0.02 & 0.11 & 0.23 & $3.01 * \star *$ \\
\hline A score for the Skin colour & -0.09 & -0.75 & -0.12 & -0.91 & 0.23 & $1.86_{*}$ & -0.08 & -0.83 \\
\hline A score for the Pulp colour & -0.08 & -0.96 & 0.19 & 1.44 & -0.07 & -0.63 & -0.08 & -0.83 \\
\hline Awareness & -0.43 & $-2.31^{* *}$ & -0.25 & $-1.80^{*}$ & -0.08 & -0.70 & 0.00 & 0.06 \\
\hline Constant & 0.71 & $19.96^{\text {the }}$ & 6.14 & $9.63^{\star \star \star}$ & -0.07 & -0.48 & -0.34 & -1.38 \\
\hline $\mathrm{R}^{2}$ & 0.21 & & 0.21 & & 0.23 & & 0.17 & \\
\hline
\end{tabular}

*** , $*$, ${ }^{*}$ mean significance at 1,5 and $10 \%$, respectively

consumer willingness to pay for the introduced dessert banana varieties.

\section{CONCLUSIONS}

From this study, all the introduced dessert banana varieties have acceptable consumer attributes though they are not superior to Gros Michel, the well known dessert banana which was used as a reference in the analysis. All the attributes of introduced dessert bananas scored above 3 on a five point hedonic scale, implying that they are acceptable and therefore have a market potential. Urban consumers are willing to pay for the introduced dessert bananas provided their attributes, as desired by the consumers, are improved. It is therefore recommended that the National Banana Research Programme in its breeding programme could improve the attributes of the introduced dessert bananas to the level of the skin appearance for KABANA $3 \mathrm{H}$, taste for Cavendish and texture for Gros Michel since these attributes were found to affect both market and consumer acceptance.

\section{REFERENCES}

Ahmadi-Esfahani, F.Z. and Stanmore, R.G. 1997. Export demand for attributes of Australian Wheat in Asia and the Middle East. Food Policy 22:145-54.

Allison, P.D. 1999. Logistic regression using the SAS system: Theory and application SAS Institute Inc., Cary, NC, USA. p.48.

Bruhn, C. M. 1995. Consumer attitudes and market response to irradiated food. Journal of Food Protection 58:175-181.

Bryan, E.M., Huffman, W.E., Shogren, J.F. and Fox, J. A. 1996. Consumer preferences for fresh food items with multiple quality attributes: Evidence from an experimental auction of pork chops. American Journal of Agricultural Economics 78:916-931

Carlsson, F., Köhlin, G. and Mekonnen, A. 2004. Contingent valuation of community plantations in Ethiopia: a look into value elicitation formats and intra-household preference variations. Working Papers in Economics 151, Göteborg University, Department of Economics. 
Deodhar, S.Y. and Intodia, V. 2002. Does Ghee sold by any brand smell as Sweden quality attributes and Hedonic price analysis of Ghee. Indian Food Industries 21(2)March-April.

FAO. 2002. Banana Information Note 2000 http:/ /www.fao.org/es/esc/esce/escr/bananas/ bane.htm)

Ferris, R.S.B., Wanda, K., Gaidashova, S.V., Tuyisenge, J., Rucibigango, M., Gatarayiha, C., Mukabazirake, E., Kagiraneza, B. and Ndirigue, J. 2002. Marketing survey of the Banana sub-sector in Rwanda. September 2002, ATDT-CIAT/ISAR/IITA-FOODNET/ CRS, Kigali, Rwanda.

Gowen, S.1995. Bananas and Plantains. Pub. Chapman \& Hall. 612pp.

Hayes, D.J. and Lence, S.H. 2000. Anew Brand of Agriculture: Farmer- Owned Brands. Reward Innovation.” Choice (Fall 2002): 2p.

IDEA, 1998. Investment in Developing Export Agriculture and Natural Resources, USAID, Kampala, Uganda.

Kangire, A., Tushemereirwe, W. and Nowakunda, K.1999. Reaction of local and exotic bananas to Fusarium Wilt in Uganda and yield of IMTP Cultivars under field conditions. Proceedings of the International Workshop on the Banana Fusarium Wilt Diseases, Genting Highlands Resort, Malaysia, 18-20 October 1999.

Karamura, D.A., Karamura, E.B. and Gold, C.S. 1996. Cultivar distribution in primary banana growing regions of Uganda. MUSAAFRICA 9:3-5.

Ladd, G.W. and Lapan, M.B.E. 1976. Price and demands for input Characteristics. American Journal of Agricultural Economics 58:21-38.

Larue, B.1991. Is wheat a homogeneous product? Canadian Journal of Agricultural Economics 39:103-17.
Motameni, R. and Shahrokhi, M. 1998. Brand Equity Valuation: a Global Perspective. Journal of Product and Brand Management 7:275-290.

NBRP. 1999. National Agricultural Banana Research Programme, Uganda. Annual Reports. Kampala, Uganda.

Nowakunda, K., Rubaihayo, P.R. and Tushemereirwe, W. 2000. Consumer Acceptability of introduced bananas in Uganda. Infomusa 9, Issue 2.

Nowakunda, K. 2001. Determination of consumer acceptability Introduced Bananas. Unpublished M.Sc.Thesis, Makerere University, Kampala, Uganda.

SAS Institute Inc., 1989: SAS-STAT User's guide version 6. $4^{\text {th }}$ Edition 1:943.

Tushemereirwe, W.K., Kangire, A., Kubiriba, J.and Nowakunda, K.1999.Fusarium wilt resistant bananas considered appropriate replacements for cultivars susceptible to the disease in Uganda. Uganda Journal of Agricultural Sciences 5:62-64.

Rosen, S. 1974. Hedonic prices and implicit markets: Product differentiation in pure competition. Journal of Political Economy 82:34-55.

Uganda Export Promotions Board. 2003. Annual Report. Kampala, Uganda.

United Nations. 2006. The Millennium Development Goals Report 2006. United Nations, Department of Economic and Social Affairs. 26pp.

Wessells, C.R. and Anderson, J.G. 1995. Consumer willingness to pay for seafood safety assurances. Journal of Consumer Affairs 29:85- 107. 